\title{
Appropriability Conditions and The Plant Variety Protection Law in Brazil
}

\author{
Yohanna Vieira Juk ${ }^{1 *}$, Marcos Paulo Fuck
}

\begin{abstract}
This article presents an overview of appropriability conditions that are impacted by the Plant Variety Protection Law (LPC) in Brazil. The LPC was drafted in Brazil in 1997 after a long discussion that involved both international and national pressure for property rights regulations. The national perspective observed the sanction of this Law as an important strategy for bridging intellectual property rights and technological development. Although a new agricultural context was created by LPC, its efficiency in promoting appropriability for high yield varieties has been questioned and its capability of including the characteristics of agricultural cultures has been contested. David Teece's approach on appropriability and complementary assets guides this analysis that also revises data provided by the National Plant Variety Protection from 1997 to 2016 , and shows that although LPC have had an important role in institutionalizing high yield research and development in Brazil, it does not immediately guarantee appropriability.
\end{abstract}

Keywords: Plant Variety Protection Law; Appropriability; Intellectual Property; Plant Breeding; Agricultural Research.

Submitted: April 30, $2020 /$ Approved: October $27^{\text {th }}, 2020$

\section{Introduction}

The means of economic appropriation of research and development $(\mathrm{R} \& \mathrm{D})$ invested in the agricultural inputs were simultaneously strengthened with the innovation process that happened in agriculture since 1960. This period, known as the Green Revolution, introduced high yield varieties and new management methods, both dependent on the use of chemical inputs. The research organization at the time was an important condition to transfer agricultural technology and technical assistance programs among countries, with an important role for public research institutes (Parayil, 2003). This productivist model changed along with institutional and technological innovations, leading to the Gene Revolution in 1990. The loss of public prominence in the new Gene Revolution and changes in the transfer of genetic materials, essential for the consolidation of the model during the Green Revolution, opened up a space for large multinational companies to become primarily responsible for these activities. However, their research is aimed at the most attractive seed markets, such as soybeans, corn, and cotton (Fuck and Bonacelli, 2009). The change in the dynamics of public research can be attributed to changes in the appropriability conditions of technologies (Atkinson et al., 2003). The role of public research centers demands attention precisely because, in the context of the Gene Revolution, these new technologies enforce the need for an active stance on part of the public sector concerning research and regulation activities (Aviani and Machado, 2015, p. 230).

This paper focuses on the analysis of intellectual property rights applied to high-yield seeds. By focusing the analysis on plant breeding activities, the most common form of protection is the plant variety protection. Plant varieties (or cultivars) can be understood as cultivated varieties of plants obtained through breeding techniques. ${ }^{2}$
Plant variety protection rights were instituted in Brazil with the Law no 9.546/1997, the Plant Variety Protection Law (Lei de Proteção de Cultivares - LPC), after a long period of political discussions that started in 1976 (Velho, 1995). The window of opportunity was forged by international pressure of the Trade-Related Aspects of International Property Rights and a new and more restrictive guideline of the International Union for the Protection of New Varieties of Plants (Union pour la protection des obtentions végétales - UPOV) (Juk, 2019). Brazil's agricultural context shifted after LPC's promulgation, by increasing specifically private agricultural research and placing national agriculture in an international scenario. Alongside this new productive context, the appropriability condition of LPC's was questioned ever since its promulgation, promoting a political movement to change the Law. The purpose of this paper is to analyze how the idiosyncrasy of agricultural species can affect the way LPC is used and how its appropriability conditions vary according to biological and production characteristics.

The neo-Schumpeterian discussion describes the innovative process as a phenomenon inserted in a political and institutional context. The theoretical contributions of David Teece (1986) and his discussion of the appropriability conditions and the role of complementary assets help us understand the importance of the appropriability regimes that define the strategies of plant breeding activities in their search for economic return.

\section{Appropriability conditions in agriculture}

To understand the appropriability conditions, it is important to comprehend the technological regime in which plant breeders that seek appropriation of their innovation process are inserted; allowing us to identify actors, institutions and strategies that can influence the appropriability conditions.

1) Post-graduate Program on Public Policies, Federal University of Paraná, Curitiba, Brazil.

${ }^{*}$ Corresponding author: yohannajuk91@gmail.com

(2) Protected cultivars must have human intervention and other technical attributes, such as "the distinction of other known cultivars, the uniformity between plants within the population, and the stability of plant characteristics in successive generations. They must also have a unique and appropriate name" (Aviani and Machado, 2015, p. 230). 
The use of intellectual property rights (IPRs) to plants is a relatively recent phenomenon when considering the long history of IPR in different areas. The increased participation of the private sector in plant breeding, initially in the development of hybrid varieties of corn in the USA, provided the impetus for an IPR framework for plant varieties to encourage innovation and private investment. However, it was later found that the protection of cultivars or other forms of protection of plant varieties were not considered a guarantee for encouraging innovations in the breeding process (Tripp, Louwaars and Eaton, 2007). Thus, the move towards rigid forms of protection, such as utility patents for plants, has been common among breeders. Srinivisan (2005) clarifies that the declining trend in the use of cultivar protection is accompanied by the high use of patents for plants, plant components, and technological processes. Two conditions contribute to the patent for plants movement and are enforced by UPOV's guidelines: the farmer's privileges (which allow farmers to keep seeds from one harvest to use in the next one) and the breeder's exception (which allows any protected variety to be used as an initial source of variation in the development of other new varieties). To meet these demands and limit the farmers' privilege, developed countries have endeavored to strengthen plant variety protections, aiming to provide better appropriability conditions (Tripp, Louwaars and Eaton, 2007; Correa et al., 2015).

While discussing the appropriability conditions provided by LPC, Carvalho (2003) concludes that it does not have a uniform effect in all agricultural segments (hybrids, varieties, vegetables, and flowers). It becomes necessary to use other assets that assist LPC in its function when in a weak appropriability condition. The author points out that the use and administration of the LPC depend on awareness about the particularities of each agricultural segment.

Discussing appropriability conditions is a topic of studies for neoSchumpeterian analysis on innovation itself. Nelson (2006) argues that intellectual property is frequently used as appropriability mechanisms, but it is not self-sufficient. Firms behavior and strategies are deeply affected by the technological environment they are inserted in. This environment defines the nature of the problems that firms must solve in their innovative activities. Malerba and Orsenigo (1993) highlighted how different opportunities, conditions of appropriability and distinct characteristics of the knowledge base can lead to new patterns of evolution. The appropriability conditions reflect the possibilities for protecting innovation that prevent imitators from acting and extract the returns from innovative activities. Some firms use a variety of means to protect their innovations - through patents, trade secrets, trademarks or the control of complementary assets.

Regarding the discussions on appropriability conditions, it is important to return to the arguments presented by Teece (1986). The author highlights that the appropriability of the innovative process is related to the nature of the technology and the sector's appropriability regime. Teece (1986) emphasizes that although intellectual property operates in the sense of ensuring ownership and economic return of innovation, this mechanism is not self-sufficient, so it is necessary, in a complementary way, the articulation with others appropriation mechanisms - legal or not. Important factors in that matter are appropriability regimes, stages of dominant design and access to complementary assets. The conditions for a regime of strong appropriability are based largely on tacit knowledge and effective legal protections; weak regimes are based on codified knowledge and ineffective legal mechanisms. Access to and exploitation of complementary assets has a prominent role in the strategies of innovators. Complementary assets include marketing services, manufacturing or even sales support. In the case of innovations in plant breeding, the main complementary assets are marketing, the influence of price mechanisms, and the means of commercialization, distribution and technical assistance.

To better understand the appropriability regimes and conditions, Carvalho (2003) describes singularities of the hybrid market, variety market, flower, and vegetable market. It is important to emphasize that the conditions indicated were presented before the promulgation of LPC (in 1997) and trends and interests about the effects of LPC may have changed in the Brazilian context. The seed industries developed way before mechanisms and legislation to protect varieties were implemented, so it is important to check which mechanisms were already available and used by these actors to guarantee appropriability (Tripp, Louwaars and Eaton, 2007).

\section{Hybrid market}

The brand was highlighted as a fundamental mechanism of appropriability that had a legal nature, together with contracts between suppliers and distributors. Learning, technical assistance, user/producer relationship and the qualification of cooperating producers were important, as well as variable appropriability tools (the hybrid corn is a good example of this market). Thus, LPC would not have a profound effect on the hybrid markets, concerning their strategies already established in other appropriability mechanisms. For seed companies, hybridization offers additional advantages. The practice of saving seeds by farmers (the farmer's privilege) is less likely to happen due to loss of quality, productive potential and uniformity in the second generation of the seed (Tripp, Louwaars and Eaton, 2007). This is a good example of a high appropriability regime, in which biological condition allow an effective legal protection.

\section{Variety Market}

Brand licensing and market alliances were already used by companies. In legal terms, brands, former Seed Law, franchise and licensing contracts were the appropriability alternatives identified in this market. In contrast to the productive configuration of the hybrid market, legal mechanisms are one of the many instruments to be used in the variety market, such as learning, marketing and distribution, technical assistance and the network of cooperating producers. This market comprehends soybean, beans, rice, wheat, cotton, sugar cane, potatoes and many other species of high commercial value.

\section{Vegetables and Flowers Market}

The strategies that are used in this market are licensing, integration and purchase of basic seeds. Considering the appropriability mechanisms, the brand was an important strategy. Regarding non-legal appropriability mechanisms, secrets, commercialization, and distribution were highlighted as complementary assets along with learning. 
The next section will analyze the appropriability conditions presented in the agricultural species 20 years after the promulgation of LPC and try to respond if this mechanism is a useful appropriability mechanism or if plant breeders developed other instruments to boost R\&D activities in Brazil.

\section{Overview of protected seeds in Brazil}

The seed market in Brazil is regulated by the Law of Seeds and Seedlings $\mathrm{n}^{\circ} 10.711 / 03$ that created the national system of seeds and seedlings, and by LPC n. 9.456/97 which covers intellectual property in seed breeding. The innovative activities of the seed industry are characterized by the transfer of technology through licensing or other means of technological exchange (Feltre, 2004). In this sense, seeds developed from breeding activities (both classical and by DNA recombination techniques) have the main role of increasing the productivity of this sector.

The seed market in Brazil reached R $\$ 10$ billion a year in 2017 (ABRATES, 2017). After a period of market consolidation that followed LPC's promulgation, a new productive configuration emerged, composed of few but large companies that are responsible for the generation, development, and production of plant varieties. Santos (2013) considers that the legal provisions enacted in the late 1990s provided a friendly environment for this new productive configuration and the performance of private companies, stimulating activities in R\&D and innovation. Although new seed multiplier companies assumed a prominent position during the 1990s, the improvement activity itself at the time was still carried out by a few companies, mainly public institutes, such as the Brazilian agricultural research corporation, Embrapa. In this new context, private companies were introduced to the market for the development of new seed technologies. It is possible to identify the presence of large conglomerates that acted in the provision of technologies with high investment and aggressive strategies to dominate the market (Santos, 2013). Thus, local and smaller companies were bought by large agrochemical companies because they have more adaptive knowledge and greater perception of the national markets. Brazil has become an important actor in the international context in the specific fields of biotechnology, seed improvement and in the development of genetically modified vegetables. Currently Brazil is one of the main agricultural leaders in the world and in 2017, agriculture and agribusiness contributed $23.5 \%$ to the country's Gross Domestic Product (GDP), this being the largest share in thirteen years according to data from Confederation of Agriculture and Livestock of Brazil (CNA). Santos (2013) points out that the market structure was so deeply changed that seed production in Brazil went from 1.6 million tons in 2001 to three million tons in the 2011/2012 harvest. In this sense, the biggest highlight in terms of segments is the production of soybean, corn, wheat, rice and forage seeds, which are responsible for more than $90 \%$ of the national production.

Today the National Registry of Cultivars (Registro Nacional de Cultivares - RNC) has over 36 thousand registered cultivars up to 2016. The RNC is a system that controls all cultivars that are good for use and commercialization but does not necessarily include protected cultivars. This information is stored in another system, the SNPC. This system contains data that 3386 seeds have a cultivar protection certificates since 1997 up to 2016. LPC was implemented in November 1997, so the first requests for cultivar protection were in December 1997 and are presented in Table 1. The largest number of registered species in RNC is of ornamental species, with 13997 cultivars, and 686cultivarsare protected in the SNPC.

The classification of plant groups and their respective cultivar protection request by year during the last 20 years are presented in Table 1 according to the categories of SNPC, which are forest, forage, fruit, vegetable, ornamental, medicinal and aromatic and agricultural. ${ }^{3}$ The specie that requests most protection certificates is soybean varieties, that have 1147 protected cultivars and is inserted in the agricultural category, followed by ornamental cultivars, that have 686 certificates, and by fruit cultivars, with 203. It is also possible to observe a decrease in the granting of certificates that reached its peak in 2011, with 262 requested certificates.

We shall present the characteristics of the seed market according to the classification of agricultural groups described in Table 1 . The purpose of this analysis is to comprehend the species that are 'protected' in the SNPC, and their peculiarities regarding the use of appropriability mechanisms.

Table 1. Evolution of the number of cultivars protected by plant group and year

\begin{tabular}{|c|c|c|c|c|c|c|c|c|c|c|c|c|c|c|c|c|c|c|c|c|c|}
\hline Species & ลू & $\stackrel{\infty}{\check{\beth}}$ & Әे & ஓ్రి & ঠ্ণి & ర్రి & હ̊̊ి & ঠ্ণ & ¿̊ํำ & ஓ̊̊ & હે & ஓ̊ํㅇ & ஓ్తి & 응 & $\overline{\bar{乛}}$ & 깅 & $\stackrel{m}{\tilde{\nu}}$ & $\underset{\nabla}{\stackrel{్}{్}}$ & 용 & 웅 & Total \\
\hline Forest & 0 & 0 & 0 & 0 & 0 & 5 & 1 & 0 & 0 & 5 & 11 & 9 & 3 & 4 & 8 & 14 & 18 & 8 & 18 & 13 & 117 \\
\hline Forage & 0 & 0 & 0 & 0 & 0 & 1 & 3 & 4 & 2 & 1 & 6 & 4 & 1 & 9 & 5 & 10 & 11 & 11 & 7 & 3 & 78 \\
\hline Fruit & 0 & 0 & 0 & 2 & 2 & 1 & 6 & 14 & 5 & 6 & 9 & 10 & 24 & 10 & 25 & 15 & 23 & 16 & 13 & 22 & 203 \\
\hline Vegetable & 0 & 0 & 0 & 0 & 0 & 3 & 1 & 9 & 7 & 0 & 11 & 10 & 3 & 8 & 7 & 11 & 15 & 16 & 23 & 8 & 132 \\
\hline Ornamental & 0 & 0 & 0 & 0 & 0 & 7 & 5 & 48 & 50 & 39 & 77 & 51 & 73 & 45 & 79 & 36 & 43 & 55 & 46 & 32 & 686 \\
\hline Medicinal and Aromatic & 0 & 0 & 0 & 0 & 0 & 0 & 0 & 0 & 0 & 0 & 0 & 0 & 0 & 1 & 0 & 1 & 0 & 0 & 0 & 2 & 4 \\
\hline Agricultural & 7 & 97 & 111 & 75 & 92 & 74 & 105 & 117 & 108 & 105 & 84 & 106 & 113 & 120 & 138 & 162 & 136 & 147 & 142 & 127 & 2166 \\
\hline Total & 7 & 97 & 111 & 77 & 94 & 91 & 121 & 192 & 172 & 156 & 198 & 190 & 217 & 197 & 262 & 249 & 246 & 253 & 249 & 207 & 3386 \\
\hline
\end{tabular}

Source: SNPC 2017.

(3) The status of cultivar certificates in the SNPC system are active, provisional, cancelled and expired by date. 
Agricultural plant group

The agricultural crops produced and protected in Brazil include peanuts, oats, coffee, cotton, sunflowers, barley, tobacco, rice, beans, sugarcane, rye, potatoes, sorghum, wheat, cowpea, triticale, corn and soybean. Among the protected cultivars, the specie with a consolidated role is the soybean that has 1147 protected cultivars. The following are wheat cultivars with 193, sugar cane cultivars with 164 and cotton with 122 . To evaluate this market and present an overview of appropriability conditions, the current section will focus its analysis on coffee, corn, sugarcane, and soybean. The choice of analyzing these cultures is to understand the different biological and productive conditions that co-exist in Brazilian most planted species. While coffee and sugar cane have a strong presence of public institutions in their R\&D activities, soybean and corn have a very different institutional design and this shows that in fact these aspects affect their appropriability conditions.

\section{Coffee}

Brazilian coffee corresponded to $36.3 \%$ of world production in 2018, according to CONAB (2018). The high productivity can be attributed to biennial crops of the Arabica species, to the technological development in the productive system and to favorable climatic conditions. The R\&D activities in coffee culture was driven by the Brazilian Coffee Research and Development Consortium (CBP\&D/Café) created in 1997 and is composed of several public research institutions such as Embrapa, Agricultural Development Company of Bahia (EBDA),Agricultural Research Company of Minas Gerais (EPAMIG), Agronomic Institute of Campinas (IAC), Agronomic Institute of Paraná (IAPAR), Capixaba Institute for Research, Technical Assistance and Rural Extension (INCAPER), Ministry of Agriculture, Agricultural Research Corporation of Rio de Janeiro (Pesagro-Rio), Federal University of Lavras (UFLA), and Federal University of Viçosa (UFV). Currently, the consortium has 45 educational, research and rural extension institutions. The purpose of the activities carried out by National Coffee Research and Development Program (PNP\&D/ Café) developed by Embrapa is in line with the Strategic Plan for the Development of the Coffee Sector, carried out by the Ministry of Agriculture. Their purpose is to increase the productivity of the coffee sector and mainly boost the quality of national production. Research activities like the one mentioned were responsible for the development of this crop, as well as for the development of new coffee cultivars. There is a low number of requests for protected coffee cultivars, except for the years 2005 and 2013, which present five requests each, and the year 2014, with three requests. The RNC has 147 cultivars registered and 18 cultivars protected with an active certificate in the SNPC. The main holders of coffee cultivars in the SNPC translate the role of national and regional public institutions in the ownership of coffee cultivars. The partnership between EPAMIG, UFV, and the Minas Gerais State Research Support Foundation, is responsible for $33.3 \%$ of protected coffee cultivar certificates, followed by IAC with $27.8 \%$ and the INCAPER with $16.7 \%$. The IAC has been developing $\mathrm{R} \& \mathrm{D}$ for the coffee culture for almost 70 years and more than $90 \%$ of the 4 billion coffee trees grown in Brazil are a result of this work (IAC, 2018). Public institutions have an important role in the culture of coffee, such as IAC and other state research institutions, such as EPAMIG, IAPAR, INCAPER. Even though intellectual property rights are used, this type of instrument is still not very representative as a strategy of appropriability in this sector.

\section{Corn}

Brazil is currently the third-largest producer of corn in the world, behind China, and the USA (USDA, 2018). Corn has its inherent characteristic and wide use of hybrid varieties. Because of this peculiarity, this crop is little affected by the use of non-certified seeds. For example, the utilization rate for certified corn seeds is above $90 \%$ and this condition is fundamental for the continuous development of technology and innovation (Santos, 2013). Brazil has 2841 corn cultivars registered at the RNC. The SNPC has only 73 cultivars, all of them are variety corn; only 35 of these protected cultivars are active. That is, 38 certificates have expired. While multinational companies such as Monsanto and Dupont account for $48 \%$ of the cultivars registered in the RNC, their dominance is not high in terms of protected cultivars, since the 13 certified cultivars from Dupont were extinguished. Embrapa and the UFV also have a relevant role, with 46 and 3 protected cultivars, respectively. The public sector is predominant in protected cultivars with $71 \%$ of protection certificates and there is no public/private partnership. According to Filho and Borghi (2016), corn seed have had major developments in the last years with 315 corn cultivars available to Brazilian producers; 215 of these cultivars have transgenic technology. The selected cultivars had genetic events aimed at pest control and resistance to glyphosate molecules, corresponding to $63 \%$ of the cultivars available on the market. The availability of new and different types of genetic changes makes it possible to adapt seeds to specific environments and regions and also makes it possible to optimize their performance.

\section{Sugarcane}

Brazil is the world's largest producer of sugarcane and develops its activities without focusing solely on sugar production, as well as offering other products that derive from sugarcane such as ethanol, cachaça, bioplastic, among others. In this sense, Albuquerque, Santa Rita and Rosário (2012) highlight that Brazil is the first country in the world in ethanol production and, consequently, conquers the foreign market by supplying biofuel as alternative energy. The development of the sugar cane industry is closely related to investments that were consolidated in the country by the National Alcohol Program during 1980. The resources invested both from the public and private sectors were essential for the development of research organizations and also for the technological leap in this industry. This effort corroborated to an increase in productivity that is mainly associated with the development of new cultivars (Rosário and Fonseca, 2008; Albuquerque, Santa Rita and Rosário, 2012). The main actors who participated in the "Sugarcane Sectoral Innovation System" acted in activities for the development and diffusion of innovations, such as the São Paulo Sugarcane Technology Center (CTC), the IAC and the Interuniversity Network for the Development of the Sugar-Energy Sector (RIDESA). There are currently 163 varieties of sugar cane registered with the RNC, and113 cultivars have permanent protection by the SNPC - another 51 are no longer protected due to the expiration of the term or have had their certificates canceled. The main holders of sugarcane 
cultivars in the SNPC indicate that CTC and IAC have considerable relevance as owners of protected cultivars, as a result of the innovative process highlighted earlier promoted by the National Alcohol Program. CTC is responsible for $18 \%$ of protected cultivars and IAC for $8.5 \%$. Other actors are also relevant, such as COPERSUCAR with $16.3 \%$ of protected cultivars, the Center for Agricultural Sciences at Federal University of São Carlos, with $11.2 \%$ of protected cultivars, and Monsanto (recently acquired by Bayer) with $11.8 \%$ of protected cultivars. It is also important to emphasize the role of RIDESA. The activities carried out by this institution were responsible for its supremacy in the market due to its cultivar's releases, being responsible for $59 \%$ of the planted area in Brazil, and for obtaining the largest bank of sugarcane germplasm in the world (Santos, 2013). According to Santos (2013), RIDESA owns 66 varieties of RB sugarcane, with 17 of these cultivars being protected in order to guarantee the exclusive right over them. The $\mathrm{RB}$ varieties were also the most planted varieties in Brazil, demonstrating their economic relevance. Thus, it is important to note that LPC was used as an appropriability mechanism for productive activities. However, Santos (2013) notes that, in addition to LPC, other complementary assets are used as a strategy such as cooperation agreements with multinationals, partnerships, licenses, and others.

\section{Soybean}

The most important crop in Brazil is soybean, which is widely grown throughout the country and is responsible for a large part of the country's agricultural exports. Brazil is only behind the USA in world grain production, responsible for 117,996 million tons. The soybean market was largely dominated by the new productive practices of the Genetic Revolution, and for that reason soybean seeds have genetically modified technology, being the most planted genetically modified crop in Brazil (Rodrigues, Lage and Vasconcellos, 2013). Teles (2018) points out that $96 \%$ of the soybean production in the country corresponds to the planting of genetically modified soybeans. It is interesting to note that soybean seeds with technological events available in Brazil come from a single private company, Monsanto (recently acquired by Bayer). However, the main holder of soybean cultivars in Brazil is Embrapa. It is important to describe a similar configuration as seen in the corn market, demonstrating the marginalization of the public sector, even with the strong presence of Embrapa in SNPC and RNC. This phenomenon is due to a process of mergers and acquisitions since before the promulgation of the LPC, with an aggressive performance of large transnational companies in Brazil, notably the companies Monsanto and Bayer (only Bayer now), Dow Agrosciences and DuPont, seeking to obtain germplasm banks adapted to the national context. The soybean seed market can be divided into two groups: the development of conventional soybean seeds, with a large number of public institutions, with emphasis on Embrapa, UFV and the Goiás Agency for Technical Assistance, Rural Extension and Agricultural Research (EMATER-GO); and the non-conventional segment, with the main role of transnational companies. It is important to note that LPC is used repeatedly for the protection of new soybean cultivars; however other appropriability mechanisms are being used by private companies and are proving to be more effective in ensuring innovative returns. This is the case of technology licensing contracts for the use of improved seeds applied by Monsanto and incorporated in its entire commercial strategy, as described by Teles (2018) and Turzi (2017). Teles (2018) points out that the company's actions are relevant for determining the appropriability and retention of royalties on genetically modified seeds. Monsanto conducted a successful campaign in changing the interpretation of LPC's farmer's privilege rights to guarantee royalties payment for Roundup-Ready. Since November 2019, Brazil allows the double protection of the Law, both LPC and Brazilian Industrial Property Law (9.279/1996) that protects genetically modify events in plants with patents. This corroborates the theoretical arguments of Nelson and Teece regarding the implications of private strategies in appropriability regimes in specific markets.

\section{Forest}

Activities related to trees' plantation play an important part in the Brazilian GDP, representing 6.1\% of the industrial GDP, according to the Brazilian Tree Industry (IBÁ, 2018). The main trees planted in the country are Eucalyptus and Pinus species. Other species such as Acácia, Araucária, Paricá and Teca, when summed with Eucalyptus and Pinus, represents 7.84 million hectares planted. Forestry production is mainly intended for the production of paper and cellulose, charcoal, solid and processed wood products and rubber. Currently the RNC has 2490 cultivars registered and there are 113 cultivars with provisional or definitive certificate in the SNPC, and 4 cultivars certificate are extinct. The main holders of protected cultivars are private companies: Fibria Celulose owns $16.9 \%$ of protected cultivars, all of Eucalyptus species, followed by Suzano Papel e Celulose company with $15.3 \%$ of protected cultivars, and Aperam Bioenergia company with $14.5 \%$ of protected cultivars. Suzano is also responsible for the largest number of cultivars registered in the RNC with 142 cultivars. The most planted eucalyptus cultivars in Brazil aren't protected by the SNPC and the companies that have records of these cultivars are not among the main holders of forest cultivars in the SNPC (Juk, 2019). This data may indicate that LPC is not yet a mechanism used by economically relevant cultivars. However, this may be a period of adaptation to the instrument, considering that cultivar's requests have increased consistently since 2012 .

\section{Forage}

Brazil is one of the most important beef producers in the world. Beef exports represent $6 \%$ of Brazilian GDP and 30\% of agribusiness GDP. Most of the Brazilian bovine production is produced in a pasture regime, and this is an important aspect because the search for better meat quality results in several investments to improve the herd's food. Grass selected and developed from R\&D aims to increase the quality of the cattle production chain in Brazil. Embrapa's ought to develop its activities in this direction, with the development of selected cultivars that correspond to more than $70 \%$ of the forage seed market. The main species of forage that are protected in the SNPC are Black Oats, Millet, Capim Colonião and Capim Pé-de-Galinha. SNPC currently has 72 protected cultivars with definitive or provisional protection certificates, and the RNC has 428 forage records. The main holder of protected cultivars is Embrapa, with $23.8 \%$, followed by the company Agro Norte, with $20 \%$ and the company Matsuda, with $15 \%$. The same companies are the main holders of forage records in the RNC, again 
with Embrapa in first place, with 55 cultivars registered, followed by the company Matsuda, with 28 cultivars, and the company AgroNorte with 26 cultivars. Embrapa's role in this sector is extremely important because of the many research projects developed by the institution. However, the private sector represents the main applicant for protected cultivars for forage crops, with $73 \%$ of protection certificates, followed by $27 \%$ of certifications for the public sector. It is important to note that having many protected cultivars does not necessarily mean prominence in the market. What supports this argument is the fact that more than $70 \%$ of the forage seeds planted in Brazil were developed by Embrapa. The institution has developed a partnership with the Association for the Promotion of Forage Improvement Research (Unipasto) that has more than 30 companies and licensed producers for seed production to disseminate new cultivars, such as the cultivars of Panicum maximum, BRS Zuri and BRS Quênia. The partnership was a meant to guarantee the exclusivity of sales and the appropriability of the efforts spent on R\&D for the development of their cultivars (EMBRAPA. 2017).

\section{Fruit}

Brazil is the third-largest fruit producer in the world, behind China and India, according to CNA (2017). Fruit production in the country represents about three million hectares and produced a total of 44 million tons in 2016 (Abrafrutas, 2018). The main fruit cultivars protected in Brazil by LPC are Vine, with 53 cultivars, followed by Apple, with 34 cultivars and Strawberry, with 19 cultivars. The RNC currently has 1514 registered fruit cultivars and the SNPC has 188 cultivars with definitive, provisional or derivative protection certification. The main holders of fruit cultivars in the SNPC is Embrapa with $16.5 \%$ of protection certificates, followed by University of California with $6.6 \%$ cultivars with permanent or temporary protection, and International Fruit Genetics with 6.2\%. Regarding registered cultivars in the RNC basis, the main holder is Embrapa again, with 288 cultivars registered. Although Embrapa is the main cultivar holder, the private sector is responsible for $66 \%$ of protected cultivars, while the public sector corresponds for $29 \%$. The remaining $5 \%$ corresponds to public-private partnership.

\section{Vegetable crop}

The vegetable market demand research and supply of new varieties because they are very susceptible to the edaphoclimatic context and to pests and diseases. This biological condition resulted in a process of introducing hybrid seeds for several species, as indicated by the Brazilian Association of Trade in Seeds and Seedlings (Abcsem, 2018). The main holders of vegetable cultivars are private companies, such as Sakata Seed Sudamerica Ltda. and Monsoy Ltda, owned by Monsanto (now Bayer). The company Sakata Seed Sudamerica operates in species of leafy, brassica, bulbs and roots, cucurbits and solanaceae. According to the company itself, since the 2000s, massive investments have been made seeking to develop seeds that are genetically adapted to the Brazilian context. The company also emphasizes the many R\&D efforts that were made, for example, the development of a lettuce cultivar that took ten years of research to finally be launched. Monsanto's operations are based on the company's brand called Seminis, which according to the company itself is the largest vegetable seed research, development, and commercialization company in the world. Private companies represent $70 \%$ of protected cultivars in this segment, followed by $26 \%$ of public institutions, and public-private partnership correspond to $4 \%$. In this sense, it is important to highlight Embrapa's role in the development of vegetable cultivars. Embrapa has a specific unit dedicated to these researches, called Embrapa Hortaliças that develops improved and adapted cultivars of vegetables. Hybrid seeds in this segment guarantee an appropriability advantage and demonstrate that investments in research with seeds with this biological characteristic already constitute a complementary asset to the protection of cultivars, benefiting the appropriability conditions in this agricultural group.

\section{Medicinal and Aromatic}

Medicinal and aromatic is a category within the SNPC system and corresponds to only two protected cultivars of Stevia, one protected cultivar of Baccharis trimera (Carqueja) and one of Macela. Baccharis trimera variety is registered in $\mathrm{RNC}$, however, there are no registered cultivars of Stevia and Macela. The main holder in the SNPC is the public sector: Embrapa has a partnership with the University of Campinas and holds the protected cultivar of Stevia; University of Campinas also holds a protected cultivar of Macela and Baccharis trimera. Nidera S. A. is the only private company and holds a protected cultivar of Stevia.

\section{Ornamental}

The southeastern region of Brazil is responsible for $65.9 \%$ of the planted area of ornamental plants. The state of São Paulo alone is responsible for $48.9 \%$ of the Brazilian flower production and a great part of this production is held by associates and producers integrated to the Cooperativa Veiling Holambra. According to a study commissioned by Sebrae (2015), other flower centers started to develop in Brazil in the states of Rio Grande do Sul, Paraná and Santa Catarina. The São Paulo productive hubs play a centralized role in productive, institutional and political dimensions in this segment, focusing on the cities of Holambra and Campinas. The main cultivars of protected ornamental plants are Roseiras, with 156 cultivars, followed by Alstroemeria, with 61, and Calancoe, with 58 cultivars. Currently, there are 13997 ornamental plant cultivars registered in the RNC, and 686 cultivars protected in the SNPC basis - 366 of these certificates are definitive or provisional. The main company holding protected cultivars is Anthura B. V. with $9.2 \%$ of protected cultivars, followed by Dekker Breeding with $6.3 \%$ and Könst Breeding with 5.6\%. Regarding cultivars registered with RNC, the main company is Van Zanten Plants BV with 945 registered cultivars, followed by Syngenta Crop Protection, with 377. It is important to highlight that all the companies mentioned are private and international, from Holland and other countries like Switzerland, Denmark, and Italy. Although public institutions were important for the genetic improvement of ornamental plants, such as the IAC that has 45 records in the RNC and no protected cultivar. Regarding the public sector's participation cultivars holding in SNPC, it is not relevant, with only $1 \%$ of the certifications of protected cultivars.

Ornamental plants have specific characteristics that determine different appropriability strategies. According to Sá and Saes (2014), 
the practice of using propagating material from the previous harvest enabled by the farmer's privilege occurs frequently in this sector, and this requires specific actions by companies that find it difficult to guarantee appropriability for their innovations. While the authors highlight the importance of LPC as an instrument that disciplined the productive chain of ornamental plants, Sá and Saes (2014) demonstrate that the farmer's privilege enabled by LPC can make the law ineffective for this segment. In order to fix this situation "... all flower breeders with operations in Brazil base their business with producers on contracts in which a non-propagation clause for their own use is mandatory." (Sá and Saes, 2014, p. 61).

\section{Conclusions}

LPC promulgation marked a milestone in the national productive configuration and reflected a new architecture of Brazilian agricultural research. Besides, Sá and Saes (2014) point out that the LPC regulated the market and corrected inadequacies that determine new relationships in the production chains in Brazil. The idiosyncrasies of the analyzed cultures allow us to understand the strategies of companies in guaranteeing the return of their innovative efforts in the improvement of cultivars and whether they use LPC, which may represent whether legislation is a viable instrument of appropriability for these actors.

The data of the analyzed cultures (vegetable, forage, fruit, forest, medicinal and aromatic and ornamental) and the specific cultures of the agricultural culture group (coffee, sugarcane, corn, and soybean) demonstrate that each segment has a different institutional architecture and strategies, and these characteristics define whether LPC is an effective appropriability mechanism. The LPC as a regulatory instrument ended up encouraging companies to participate in the seed market. With the exception of the sugarcane, coffee and corn cultures, that have a strong presence of the public sector as the holder of protected cultivars, all other crops demonstrate high participation of the private sector in cultivar protection certificates. However, the number of protected cultivars by a holder cannot be translated into productive relevance - the lack of data about this aspect in Brazil makes it difficult to elaborate concrete analyzes about the real relevance of protected cultivars in the marketing of seeds. Specific crops such as soybean, and sugarcane, for example, have statistics on this subject and allow us to perceive the most relevant actors in the use of improved cultivars.

It is also important to point out that the productive strategies have political implications, as sugar cane and ornamental breeders formed an articulated lobby to change the legislation on their behalf, aiming to restrict the Law in order to guarantee appropriability for their innovation activities(Juk, 2019); and Monsanto's efforts in changing the interpretation of LPC's concepts to ensure royalty payments for Round-up Ready seeds in 2019.The argument about the use of illegal seeds is recurrent as a problem to ensure the return of innovative activities of seed companies. The case highlighted in this sense is again of soybeans, in which other mechanisms of appropriability, already available before the institutionalization of the Law, are more efficient as described by Turzi (2017) and Teles (2018). Sá and Saes (2014) on strategies and productive structures of ornamental plants report a similar practice as a way of collecting royalties and controlling the use of illegal seeds.

The national productive configuration of the seed market and agricultural research has been profoundly changed in recent decades. The data from SNPC (2018) and RNC (2018) demonstrate that Embrapa is still a strong player in both registered and protected cultivars, but again, this does not mean market presence. Public research institutions are displaced, mainly due to changes in the intellectual property conditions of the technologies developed, and in order to survive new practices and partnerships might have to be developed (Bin et al., 2013; Atkinson et al., 2003)

\section{References}

Albuquerque, P. P. de; Santa Rita, L. P.; Rosário, F. J. P. (2012). Interações Tecnológicas na Indústria Sucroalcooleira de Alagoas: Análise do Sistema Setorial de Inovação. Revista de Administração e Inovação, v. 9, n. 2, p. 149-174.

Atkinson, R. C. et al. (2003) Public sector collaboration for agricultural IP management. Science, New York, v. 301, n. 5630, p. 174-175.

Aviani, D. M., Machado, R. Z. (2015) Proteção de Cultivares e Inovação. In: Cássia Isabel Costa Mendes (Orgs.) Propriedade Intelectual e Inovações na Agricultura. - Brasília; Rio de Janeiro: CNPq, FAPERJ, INCT/PPED, Ideia D; p. 225-242.

Bin, A.; Gianoni, C.; Mendes, P. J. V.; Rio, C.; Salles-filho, S. L. M.; Capanema, L. M. (2013). Organization of Research and Innovation: a Comparative Study of Public Agricultural Research Institutions. Journal of Technology Management \&Innovation. v. 8, p.209-218.

Carvalho, S. P. (2003). Propriedade intelectual na agricultura. Tese de doutorado. Universidade Estadual de Campinas.

Correa, C. M.; Shashikant, S.; Meienberg, F. (2015). Plant Variety Protection in Developing Countries: A tool for designing a Sui Generis Plant Variety Protection System: An alternative to UPOV 1991.Association for Plant Breeding for the Benefit of Society.

Feltre, C. (2004) Mecanismos de apropriabilidade das inovações tecnológicas na indústria de sementes. In: XI SIMPEP, Bauru/São Paulo.

Fuck, M. P.; Bonacelli, M. B. M. (2009). Institutions and Technological Learning: Public-Private Linkages in Agricultural Research in Brazil and Argentina. Journal of Technological Management and Innovation, vol. 4, p. 33-43

Juk. Y. V. (2019). Tramitação de alternativas da Lei de Proteção de Cultivares no Brasil. Tese de doutorado. Universidade Federal do Paraná.

Malerba, F.; Orsenigo, L. (1993). Technological Regimes and Firm Behavior. Industrial and Corporate Change, vol. 2, p. 45-71. 
Parayil, G. (2003). Mapping technological trajectories of the Green Revolution and the Gene Revolution from modernization to globalization. Research Policy, 32, p.971-90.

Rodrigues, R.; Lage, C. L. S.; Vasconcellos, A. G. (2013). Implication of Legal References on Technological Dissemination: A Study on Transgenic Soybeans Resistant to Glyphosate Herbicide in Brazil. Journal of Technology Management \& Innovation, vol. 8, p. 219-227.

Rosário, F. J. P.; Fonseca, M. G. D. (2008). Transformações industriais e sistemas setoriais de inovações: progresso técnico e implicações na dinâmica da agroindústria sucroenergética no Brasil, Revista de Economia Política do Desenvolvimento, vol. 1, n. 2, p. 95-134.

Sá, C.D. e Saes, M. S. M. (2014). Propriedade intelectual na cadeia de flores e plantas ornamentais: uma análise da legislação brasileira de proteção de cultivares. Revista Brasileira de Inovação. vol. 14, No. 1, p. $49-76$

Santos, F. S.et al.(2012).Evolution importance and evaluation of cultivar protection in Brazil: the work of the SNPC. Crop Breeding and Applied Biotechnology. S 2, p. 99-110.

Santos, P. E. de C. (2013) Marcos Regulatórios, Inovações Biotecnológicas e a Concentração da Indústria de Sementes de Soja, Milho e Algodão no Brasil. Tese de Doutorado. Universidade de Brasília.
Srinivasan, C. S. (2005). The International Trends In Plant Variety Protection. Journal of Agricultural and Development Economics. vol. 2, No. 2, pp. 182-220

Teece, D. (1986) Profiting from technological innovation: implications for integration, collaboration, licensing and public policy. Research Policy, v. 15, p. 285-305.

Teles, G. (2018) A dinâmica da inovação e da apropriabilidade na produção de sementes de soja no Brasil. Dissertação de Mestrado. Universidade Federal do Paraná.

Tripp, R.; Louwaars, N.; Eaton, D. (2007). Plant Variety Protection in Developing Countries: a report from the field. Food Policy. v. 32, p. 354-371.

Turzi, M. (2017). The Political Economy of Agricultural Booms: Managing soybean production in Argentina, Brazil, and Paraguay. Palgrave Macmillan. Buenos Aires, Argentina.

Velho, P. E. (1995) Análise da controvérsia sobre a lei de proteção de cultivares no Brasil: implicações socio-econômicas e os condicionantes políticos para o seu encerramento. Tese de Doutorado. Universidade Estadual de Campinas, Campinas. 
